\title{
THE BILL OF RIGHTS AND THE INDIAN ACT: EITHER? OR?
}

\section{R. MICHAEL M'GONIGLE*}

A review of cases concerning the relationship between the Bill of Rights and the Indian Act shows judicial confusion. The author analyzes the three major Supreme Court of Canada decisions and shows how "equality before the law" has been defined. He then applies the American "reasonable classification" test to the relationship by identifying the purpose of the above Acts to see if they apply to all persons who are similarly situated with respect to the said purpose. Mr. M'Gonigle concludes that the test is applicable to distinguish between a discriminatory exercise of statutory power and one which reflects concern for the Indians, and further suggests the manner in which the three cases and all future cases should be judicially approached.

\section{INTRODUCTION}

Although much has been written on the relationship between the Bill of Rights ${ }^{1}$ and the Indian Act, ${ }^{2}$ judicial decisions on the issue have been confused, inconsistent and undirected. The problem is well-known. While the British North America Act, s. 91(24), confers authority on the Dominion Parliament to regulate "Indians and the lands reserved for the Indians", that same Parliament, in 1960, enacted the Canadian Bill of Rights which, by s. 2, requires that federal laws be construed in light of the principle elucidated in 8.1 that:

1. . . there have existed and shall continue to exist without discrimination by reason of race, national origin, colour, religion or sex, the following human rights and fundamental freedoms, namely, ... .

(b) the right of the individual to equality before the law. . . .

Superficially the statute and the parliamentary power are in conflict. A resolution is required and it will have to come not in a challenge to the statutory power itself (which cannot, of course, be amended by a statute of Parliament), but through control on its exercise under the Indian Act.

As mentioned, the topic is one on which much has been written and the test I propose to apply to the cases, the "reasonable classification" test, is not new. However, given the continued diversity of judicial and academic opinion and the absence in the cases of any imminent resolution of the problem, a thorough exposition and application of this alternative approach is needed. After a brief discussion of some of the background issues involved in the cases, I propose, therefore, to consider the "reasonable classification" test in the context of the Indian Act and to apply it to the three major cases so far decided by the Supreme Court. It is hoped that this will provide a workable, consistent and persuasive basis for decision that will do justice to both statutes as well as to the many interests involved.

Three major cases have arisen on this issue- $R$. v. Drybones, ${ }^{3}$ A.G. Canada v. Lavell; Isaac v. Bedard ${ }^{4}$ and A.G. Canada v. Canard. ${ }^{5}$

- B.A. (U.B.C.), M.Sc. (London School of Economics), LL.B. (Tor.), presently Research Associate at the Institute of International Relations, University of British Columbia, Vancouver.

' (An Act for the Recognition and Protection of Human Rights and Fundamental Freedoms) R.S.C. 1970 , Appendix III.

2 (An Act Respecting Indians) R.S.C. 1970, c. I-6.

${ }^{3}$ [1970] S.C.R. 282, 10 C.R.N.S. 334, 71 W.W.R. 161, [1970] 3 C.C.C. 355, 9 D.L.R. (3d) 473

- (1973) 23 C.R.N.S. 197, 38 D.L.R. (3d) 481, [1974] S.C.R. 1349, 11 R.F.L. 333.

s (1975) 52 D.L.R. (3d) 548, [1975] 3 W.W.R. 1, 4 N.R. 91. Judgment of Manitoba C.A. at [1972] 5 W.W.R. 678. 
Drybones was decided in 1970 and was the first decision to meet head on the argument that a statute was in conflict with the Bill of Rights. Previously, courts had either skirted the issue or otherwise explained it away. 6 The case concerned an Indian, Drybones, who was convicted under s. 94(b) of the Indian Act for being drunk off the reserve. The section reads in part:

\section{An Indian who ... .}

(b) is intoxicated ...

off a reserve, is guilty of an offence and is liable on summary conviction to a fine of not less than $\$ 10.00$ and not more than $\$ 50.00$ or to imprisonment for a term not exceeding three months. . . .

The problem was that under the generally applicable Liquor Ordinance of the Northwest Territories, non-Indians could only be convicted if drunk in "a public place" and even then would be liable to no minimum fine and to a maximum imprisonment of only 30 days. The "special treatment" of Indians under the Indian Act was exacerbated by the fact that there were no reserves in the N.W.T. so that any intoxicated Indian was guilty of an offence under the Act. The issue was therefore concerned with the more severe treatment imposed under the federal statute when compared to the general ordinance which was also under federal authority. The Supreme Court found the difference in treatment (or, at least, the harsher treatment under the Indian Act) to be discriminatory and it overturned Drybones' conviction.

The second case, Lavell, steps back from the aggressive posture taken in Drybones. The issue was simply a challenge to s. $12(1)(b)$ of the Indian Act. That section disentitles any Indian "woman who married a person who is not an Indian" from being registered as an Indian and therefore, under the definition of an Indian, from being an Indian. ${ }^{7}$ All rights as an Indian-in particular, access to residence on the reserveare thereby removed. There was no equivalent provision for Indian men marrying white women. Indeed, by s. 11(1)(f), such white women would become registered as full Indians! Nevertheless, these provisions constituted central aspects of the Act and, in order to avoid the result in Drybones, the Court restricted the reasoning in that case to its particular facts and postulated a new definition of "equality before the law." The decision is confusing but, in light of the controversy surrounding it, not altogether surprising.

The third case, Canard, reveals indifference and paternalism on the part of the Federal Department of Indian Affairs. After the accidental death of her husband, Mrs. Canard applied for and was appointed administratrix of her husband's estate under the general Manitoba law. As she and her husband were both Indians, however, s. 42 and s. 43 of the Indian Act also applied, vesting all testamentary jurisdiction in the Federal Minister (s. 42(1)) and allowing him to appoint the administrator of the estate (s. 43(a)). In this case an administrator was appointed and a civil action on behalf of the state commenced against the person causing her husband's death-all without the consultation or even notification of Mrs. Canard. Reversing a decision by the Manitoba Court of Appeal, the Supreme Court held that any discrimination that

\footnotetext{
- See Tarropolsky, The Canadian Bill of Rights from Diefenbaker to Drybones, (1971) 17:3 McGill L.J. 422.

7 Any method of "status" definition is prone to distortions in application although this particular one is especially blatant. For the pros and cons of various methods, see Sanders, The Bill of Rights and Indian Status, (1972) 7 U.B.C. L. Rev. 81.
} 
might have occurred was not in the statute's vesting the Minister with powers that might be exercised discriminatorily, but in the actual exercise of the powers through the regulations and administration of the Act. As the method of appeal against such transgressions had not been properly taken through the Federal Court, no consideration of the discrimination was permissible.

\section{THE OPERATION OF THE BILL OF RIGHTS}

Throughout the "equality" cases, the courts have sought to establish what sort of conflict should result in the invocation of the Bill of Rights. No agreed policy has arisen.

In the Drybones case, equality before the law was found to have been denied because Drybones was treated "more harshly" under the Indian Act than were citizens in general under the federal legislation (the Territorial Liquor Ordinance). This comparative basis for the determination of "equality before the law" is both too broad, in that a comparison with other legislation is mandatory, and too narrow, in that it would surely be inapplicable where the other legislation is provincial and not federal. With regard to this latter point, Pigeon $J$. commented in Drybones:8

Its [s. 91(24)] very object in so far as it relates to Indians . . . is to make legislation applicable only to Indians as such and therefore not applicable to Canadian citizens generally. This legislative authority is obviously intended to be exercised over matters that are, as regards persons other than Indians, within the exclusive legislative authority of the Provinces. Complete uniformity in provincial legislation is clearly not to be expected. . . . Equality before the law in the sense in which it was understood in the courts below would require the Indians to be subject in every province to the same rules as all others in every particular not merely on the question of drunkenness.

In effect Mr. Justice Pigeon was saying that legislation regarding Indians would per se be found contrary to the Bill of Rights if the comparative test espoused in Drybones were accepted. At the time, Tarnopolsky argued that Drybones and the Bill of Rights were restricted to inequalities existing within federal statutes, the "laws of Canada", and could therefore not apply to inequalities with regard to provincial laws. ${ }^{10}$ Either way, the decision does not provide us with a meaningful general test of "equality before the law" though it is an important first exercise of the judicial powers conferred by the Bill of Rights. As one commentator has written:11

If we accept that the guarentee of equality before the law should be qualified by the federal principle of diversity between legislative jurisdictions, then we have to conclude that Drybones was wrongly decided.

In the Lavell case, the source of inequality was clearly between two provisions within one statute-the Indian Act. The inequality was manifest-one provision excluded Indian women who married nonIndian men, the other did not exclude Indian men who married nonIndian women. But, the basis for inequality was still a comparative one. In Canard, however, Dickson J.A. (as he then was) of the Manitoba

\footnotetext{
Supra, n. 3 at 303.

9 See Bill of Rights, R.S.C. 1970, Appendix III, s. 5(2).

10 Supra, n. 6 at 456.

"Hogg. The Canadian Bill of Rights-Equality Before the Law, (1974), 52 Can. Bar Rev. 263. This is not entirely accurate (on the facts) as the Liquor Ordinance was not provincial legislation.
} 
Court of Appeal stated what seems to be the only sensible interpretation of "equality before the law":12

I also recognize the validity of the argument advanced in Drybones that the question of whether a piece of federal legislation has been rendered inoperative should not rest upon the law of any province or territory, for its operation would then vary from province to province. . . . The inequality does not arise through conflict between a federal statute with a provincial statute. It arises through conflict with the Bill of Rights and a federal statute. The Bill of Rights has capacity to render inoperative racially discriminatory legislation, whether or not there be provincial legislation touching the subject matter.

Chief Justice Laskin agreed with this position in his dissent in the same case: ${ }^{13}$

The effect of the judgment of Dickson J.A. is to measure the operation of a federal statute . . . by the guarantees (if I may so term them) of the Canadian Bill of Rights alone, and thus to treat those guarantees as requiring not only comparative conformity to their terms but conformity by a challenged statute alone.

I do not find this to be other than a proper appreciation of what the Canadian Bill of Rights says.

Even at this stage there was not unanimous consent on the point: Ritchie J. continued to insist upon a comparative assessment of rights available under federal and provincial law, ${ }^{14}$ while Beetz J. suggested that a condensation of the general principles decipherable from all provincial laws would yield a sort of jus gentium as a standard of comparison.15 But surely even this is inadequate as it is legislative discrimination per se that is rejected and, as Laskin C.J. argued: ${ }^{16}$

... [it] is the premise of our legal system that no legal permission is needed to do anything or act in any manner not prohibited by law, whether statute law or common law.

This is the approach that is implicit in the "reasonable classification" analysis.

Even when legal inequalities are discovered, what can the Bill of Rights do about it? S. 2 of that statute states that:

Every law of Canada shall, unless it is expressly declared by an Act of Parliament that it shall operate notwithstanding the Canadian Bill of Rights [i.e. the non obstante clause] be so construed and applied as not to abrogate ... any of the rights or freedoms herein recognized and declared. . . . (emphasis added)

One of the major sources of restriction on the operation of the Bill of Rights has been the phrase "construed and applied". In the early case of $\boldsymbol{R}$. v. Gonzales, ${ }^{17}$ Davey J. of the British Columbia Court of Appeal held that the Bill of Rights was an interpretative statute only and did not affect a statute that could not be "construed and applied" in accordance with the Bill of Rights. That is, it could affect a statute that could be interpreted either as discriminatory or not but it could not declare to be non-operative a provision that could only be read as discriminatory. The

12 [1972] 5 W.W.R. 678 at 691.

13 Supra, n. 5 at 552-3. Mr. Justice Laskin cites cases not connected to the Indian Act which confirm this viewpoint.

14 Id. at 563. Ritchie J.'s argument misses the point as it is not being treated "differently" which is at issue so much as being treated differently merely because of their race when that was an irrelevant and discriminatory factor in the context of the particular legislation.

is Id. at 579 .

${ }^{26}$ Id. at 553 .

17 (1962) 32 D.L.R. (2d) 290. 
illogicality of this approach is obvious and Cartwright C.J. in the case of Robertson and Rosetanni v. Q. argued against it: ${ }^{18}$

The imperative words of s. 2 of the Canadian Bill of Rights . . appear to me to require courts to refuse to apply any law, coming within the legislative authority of Parliament which infringes freedom of [religion, in this case]. ... In my opinion where there is an irreconcilable conflict between another Act of Parliament and the Canadian Bill of Rights, the latter must prevail.

This issue came to a head in Drybones with the majority of the opinion that the Bill of Rights could render a discriminatory provision "inoperative". Ritchie J., speaking for the majority, strongly opposed the restriction of the Bill of Rights to just a rule of "construction". To see it thus was inconsistent with the power of Parliament to prevent the application of the Bill of Rights when it so wished through the non obstante clause and it was: 19

... to strike at the very foundations of . . . [its] character as a statutory declaration of the fundamental human rights and freedoms which it recognizes. . . .

There was not unanimous agreement on this point as Abbott J. argued that: ${ }^{20}$

The power to make such a delegation cannot be questioned but, in my view, it would require the plainest words to impute to Parliament an intention to extend to the courts, such an invitation to engage in judicial legislation.

In this attitude Mr. Justice Cartwright now agreed, reversing ("after most anxious consideration") the position he had taken in Robertson and Rosetanni. Mr. Justice Pigeon agreed as well, feeling that the alternative approach would have "fundamentally altered the status of the Indians in [an] indirect fashion". ${ }^{21}$ Although it will be argued that this misconstrues what should be the effect of judicial intervention in discrimination cases, Mr. Justice Pigeon's comment is particularly interesting in light of similar opposition to judicial intervention from native peoples themselves.

Considering this trepidation in a case involving only a minor provision of the Indian Act, it is not surprising to see the far greater caution in Lavell where the challenged provision was crucial to the very exercise of the constitutional power over Indians. Despite Mr. Justice Pigeon's comments to the contrary, however, the plurality opinion in Lavell only partly restricted the decision in Drybones. These judges now held that legislation necessary for the fulfilment of a constitutional power was not to be rendered inoperative in the absence of "... plain statutory language expressly enacted for the purpose". ${ }^{22}$ Subsequently, Beetz $J$. in the Canard case asserted that such a rule would apply only to those incidents, such as the definition of status, that are "not remote nor indirect" but are a "necessary incidental consequence" of the exercise of the constitutional power. ${ }^{23}$ Although this conclusion would mean that the Bill of Rights would not operate to override a constitutional power, it does not mean that the statute is, in general, restricted to a "rule of construction". Indeed the ratio of Drybones is

\footnotetext{
18 [1963] S.C.R. 651 at 662.

19 Supra, n. 3 at 293.

$20 \mathrm{Id}$. at 299.

21 Id. at 304.

22 Supra, n. 4 at 206 (per Ritchie J.).

zo Supra, n. 5 at 576.
} 
certainly the opposite. What it does point to, however, is the difficulty in reconciling a judicial power to declare inoperative legislation based on "discrimination by reason of race" with the valid legislative power of Parliament over the subject of "Indians".

\section{EQUALITY BEFORE THE LAW-IN SEARCH OF A DEFINITION}

The first case setting out a definition of "equality before the law" was $R$. v. Gonzales where it was considered to mean that the law should apply ". . . equally without fear to all persons to whom the rights extend. ${ }^{24}$ This approach taken by Tysoe $\mathrm{J}$. was expressly rejected in Drybones, where Ritchie J. commented that it would permit the most glaring discrimination against a class "... so long as all the other members [of a class] are being discriminated against in the same way. ${ }^{25}$ As Mr. Justice Hall pointed out, the Gonzales approach was similar to the "separate but equal" doctrine that had been rejected in the famous American judgment of Brown v. Board of Education. ${ }^{26}$

An alternative definition was proposed by $\mathrm{Mr}$. Justice Ritchie in Drybones but specifically in the context of the conflicting federal statutes under consideration and without attempting any exhaustive definition. "Inequality before the law" existed in that case where: ${ }^{27}$

... it is made an offence punishable at law, on account of race, for him [Drybones] to do something which his fellow Canadians are free to do without having committed any offence...

This presented the Court with a broad, comparative test which, if freely applied, could lead to the invalidation of much of the Indian Act. Mr. Justice Ritchie discovered this problem in Lavell where, in order to uphold the impugned provision in that case, he retreated from the definition propounded in Drybones. First, he restricted the Drybones test to criminal cases (where it was made an "offence") and to cases of regulation of Indians "off" the reserve. With respect, the former restriction completely misconstrues the thrust of the Drybones ratio as Mr. Justice Laskin was quick to point out (see below). Mr. Justice Ritchie's second argument, moreover, had no validity under the BNA Act or the Indian Act which did not just extend to Indians on the reserve. ${ }^{28}$ Had Ritchie J. elucidated some criteria by which to distinguish acceptable from unacceptable differences in treatment in light of the purposes of the Act, this argument might have merited greater interest. He did not do this, however, and, having distinguished Drybones, he formulated an alternative test for equality before the law applicable to the instant case. Equality before the law was to be found in the equal subjection of all to the "administration or application of the law enforcement authorities in the ordinary courts of the land."29 Without expanding upon this conclusion, he decided that s. 12(1)(b) of the Indian Act entailed no such inequality and was, therefore, not contrary to the Bill of Rights.

24 Supra, n. 17 at 297.

25 Supra, n. 3 at 297.

26 (1954) 347 U.S. 483.

27 Supra, n. 3 at 298.

28 See Tarnopolsky, Canadian Bill of Rights 153-56. See also Ritchie J. in Lavell, supra, n. 4 at 210-16.

29 Supra, n. 4 at 211. This was a test that was long ago rejected in the American courts and which does seem almost as limited as was the ratio in Gonzales. See also Yick Wo v. Hopkins (1886) 118 U.S. 356. 
Laskin J. (as he then was) dissented. Firstly, he rejected the arbitrary distinction that was made of the Drybones case when, after all, the ". . gist of the judgment lay in the legal disability imposed upon a person by reason of his race. . . ."30 Mr. Justice Laskin's approach was the antithesis of Ritchie J.'s narrow and very convoluted test. Instead, he formulated a simple, clear but very broad approach. Whereas in his earlier judgment, Curr v. Q.,31 he had emphasized the need to find an infringement of one of the rights and freedoms outlined in $s$. 1 , regardless of discrimination in one of the forms enumerated, in Lavell, an infringement of either the rights or the discrimination section alone would be struck down: ${ }^{32}$

... [F]ederal legislation, which might be compatible with the command of "equality before the law" taken alone, may nonetheless be inoperative if it manifests any of the prohibited forms of discrimination.

This seems to conflict with the plain meaning of $\mathrm{s}$. 1 which specifically deals with the forms of discrimination in terms of the rights and freedoms named therin. Indeed, Mr. Justice Laskin has been accused of engaging in a "judicial redrafting" of the Bill of Rights. ${ }^{33}$ It is, however, possible to avoid this criticism if one adopts a definition of "equality before the law" which would itself inevitably reflect the presence of discrimination. This is the basis of the "reasonable classification" approach.

\section{AN ALTERNATIVE APPROACH: LEGITIMATE LEGISLATIVE PURPOSE AND REASONABLE CLASSIFICATION}

The United States has had long experience with the protection of equality before the law through the 14th amendment to its Constitution. This amendment was held not to invalidate special laws that: ${ }^{34}$

... may press with more or less weight upon one than upon another so long as they are designed not to impose unequal or unnecessary restrictions upon any one, but to promote, with as little inconvenience as possible, the general good.

To identify when such special laws also violate the right to "equal protection before the law" is the function of the "reasonable classification" test. Outlined by Tussman and tenBroek, ${ }^{35}$ it simply requires that laws which distinguish one group from another be based upon classifications that are reasonable and that a "reasonable classification is one which includes all persons who are similarly situated with respect to the purpose of the law," 36 the purpose itself not being discriminatory per se. ${ }^{37}$

This approach clearly then involves the Court with two broad questions: to identify the purpose of the legislation and to evaluate the reasonableness of the classifications for those affected by it. Not only does this offer the courts the opportunity to undertake a more penetrating and flexible analysis of the purposes and actual impact of

\footnotetext{
is' Id. at 224.

" [1972] S.C.R. 889

32 Supra, n. 4 at 226-27 (per Laskin J.).

:3 Matas, Indian Women's Rights, (1974) 6:1 Man. L.J. 195.

34 Barbier v. Connolly (1885) 113 U.S. 27 at 31

is Tussman and tenBroek, The Equal Protection of the Laws, (1949) 37: 3 Calif. L. Rev. 341.

iti Id. at 346.

37 Id. at $353-61$.
} 
the challenged legislation but it also makes a reasonable linkage between the right to equality before the law and the prohibition against discrimination. That is, any law the effect of which is to treat restrictively a particular group (especially one that is defined by a classification that is "forbidden" or "suspect"- such as race, religion, sex, etc.) must be justified in terms of a rationally acceptable purpose which treats a characteristic that is "reasonably" associated with that group as defined. Especially with some types of groups, this requirement is an extremely difficult one to fulfil and if, upon examination, the only basis for classification is a prejudice or discrimination against the group, there is ipso facto inequality before the law and the law must be "construed and applied" so as to remedy that inequality.

This method of analysis is, I suggest, perfectly suited to the application of the Bill of Rights to the Indian Act especially in light of the constitutional relevance of "Indians and lands reserved for the Indians" under the BNA Act, s. 91(24). With this test, a purely discriminatory exercise of legislative power can be distinguished from one that reflects a concern for "Indians" as an entire cultural and sociological entity. It is, I suggest, only through such an approach that the directions of the BNA Act can be made to work with the "quasiconstitutional" intention of the Bill of Rights and it is also this approach which offers the best method of resolving the divisions that have been evident in the decisions of the Supreme Court.

\section{A. Legitimate Legislative Purpose}

Does the Bill of Rights forbid some legislative classifications entirely? Is there any "purpose" that can never be the basis of a "reasonable classification"? The answer to these questions is, I suggest, "Yes" but it is not those instances enumerated-race, sex, national origin, colour and religion-that are absolutely forbidden. On the contrary, there is only one such prohibited class of legislative classification-those that are "discriminatory".

Unfortunately, the definition of "discrimination" in s. 1 of the Bill of Rights has not been an issue of judicial discussion although it would seem to be of the most central significance to an interpretation of the statute. If the above interpretation is correct, "discrimination" should not be interpreted in a neutral, dictionary sense (to discriminate is to distinguish or separate) but in its pejorative, common usage sense (to discriminate is to separate unfairly or without reason). This is by no means universally accepted. Writing in the Canadian Bar Review, one commentator expressed the opinion that: ${ }^{38}$

It is surely the intention of these words to deny that there are any distinctions whatsoever on the basis of which some Canadians might be excluded from the protections afforded by the enumerated rights.

This statement is either tautological (whereby any distinctions are unacceptable distinctions if they would, for example, deny equality before the law) or else it negates the very purpose of the law, which is to classify. $^{39}$ The point is surely that the legislature does make distinctions between groups based upon accepted purposes and values and these result in actual differences in the rights of groups under the law. In this

3A McLaughlin, Case Comment on $R$. v. Smythe, (1973) Can. Bar Rev. 517 at 518.

39 Id. at 543-4. As Tussman wrote- "We thus arrive at the point at which the demand for equality confronts the right to classify." 
factual sense they are "unequal" but, being fairly so, there is no inequality in their being treated differently. It is only where the original distinction is itself based upon an unacceptable purpose"discrimination"-that there is inequality. In that case, equals are not being treated equally.

More recently, Professor Lyon has taken a similar approach in arguing that $8.1: 40$

... constitutes an absolute prohibition against discrimination by reason of race, national origin ... . when it comes to the enumerated rights and freedoms. Parliament is saying in effect that there can never be a rational justification for violating one of these rights and freedoms.

In applying this strict test to the Lavell case, Professor Lyon finds discrimination to exist because of "differential treatment" accorded to women. A similar application of an absolute racial prohibition is applied to the Drybones case. No question of why there was a difference in treatment is raised in either case and the relevant provisions are readily declared to be inoperative. This approach is persuasively clear but it fails, I feel, to do full justice to the situation as it exists. For one thing, race is not an absolutely prohibited classification or, if it is, much of the Indian Act has been invalidated and Mr. Justice Pigeon's criticism that Parliament has "fundamentally altered the status of the Indians in [an] indirect fashion" 41 is correct. Likewise, it can be queried whether the use of sexual criteria would always be contrary to the Bill of Rights where there was, for example, a legitimate underlying "biological or physiological rationale". ${ }^{2}$ That these classifications would be discriminatory is clear from Professor Lyon's assertion that the Indian Act is "inherently repugnant" 43 to the Bill of Rights.

The implications of such an absolutist approach do justice to neither the Indian Act nor the Bill of Rights. Professor Lyon advocates that a non obstante clause be introduced so as to "free the development of the Canadian Bill of Rights of these nearly insoluble problems". ${ }^{44}$ Professor Lyon's argument fully evaluates the difficult and conflicting issues at stake but his conclusions are, I feel, unduly pessimistic as to what the Court could and should accomplish. Is the Bill of Rights to be restricted to only the easier, less significant problems? ${ }^{45}$ Are Indians to be

40 Lyon, A Progress Report on the Bill of Rights, (1976) 3:1 Dalhousie Law Journal 39 at 52. Professor Lyon is not absolutely consistent in his use of the absolute prohibition as he recognizes in the Canard case that a "differential treatment because of race" is not necessarily "racial discrimination" because of s. 91(24). Having found the prohibition no longer "absolute" he also introduces the idea that his first test of discrimination by reason of race should not apply as the disputed sections "were enacted in good faith for an obviously
legitimate purpose" (at 60).

1 Supra, n. 3 at 304.

12 Supra, n. 4 at 226 (per Laskin J.). Mr. Justice Laskin's full statement on this point was: "I doubt whether discrimination on account of sex, where as here it has no biological or physiological rationale, could be sustained as a reasonable classification even if the direction against it was not as explicit as it is in the Canadian Bill of Rights."

4) Supra, n. 40 at 57 . Such a debate is going on in an oblique fashion within the Supreme Court itself. Mr. Justice Laskin stated earlier in Lavell a position very similar to that of Professor Lyon. He opposed "leap[ing] over" 8. 1 and argued that "Discriminatory treatment on the basis of race or colour or sex does not inhere in that grant of legislative power" (s. 91(24)) at 228. The Chief Justice repeated this position in Canard (at 557. 8). This is certainly a reasonable attitude but again because the use of the term "discriminatory" is unclear. Otherwise, one can not but aympathize with Beetz J.'s comment in Canard that: "Nevertheless, it is not easy so to legislate irrespective of race or sex when it is race which has to be defined and, assuming it were possible if one were to start afresh, it may be next to practically impossible so to do for an already existing group which has been sociologically and legislatively defined since before Confederation. The alternative would appear to have been the abolition of the present Indian status or of any Indian status." (At 576.)

4. Supra, n. 40.

4s One is reminded of Jessup's call for a "modest objective for international law . . between like-minded maximis non curat praetor." 
banished from the protection of the Bill of Rights? ${ }^{46} \mathrm{Or}$, conversely, although the protection of minorities has no explicit place in the statute, is it conceivably inconsistent with it? ${ }^{47}$ One would, I suggest, do better to avoid absolutes and search instead for classifications that are reasonable in light of rational legislative purpose.

If discrimination is to be used as it is advocated here, then Laskin J. was not, with respect, correct when he dismissed the American cases on the subject as "having at best marginal relevance because the Canadian Bill of Rights itself enumerates prohibited classifications which the judiciary is bound to respect". 48 On the contrary, there is much to be learned from the American experience. For example, Tussman pointed out the "theoretically insurmountable" 49 problem implicit in closing the list arbitrarily on an $a$ priori set of forbidden classifications. This has proven to be prescient of both the American and Canadian experience as the Supreme Court in Canada has held that the list specified in s. 1 of the Bill is not, in effect, a closed list. Rather, as Laskin J. noted, s. 1 does not have the effect of "making the existence of any of the forms of prohibited discrimination a sine qua non of its operation".50 It is the infringement of the rights and freedoms themselves that is important. Discrimination results in such an infringement.

Recent American cases also continue in their avoidance of an absolute list of prohibited forms of discrimination. Instead, they refer to a heavier burden of justification according to some "overriding statutory purpose" in cases involving those classifications such as race and sex which are "extraordinarily suspect".51 "Benign discrimination" such as that setting quotas for the employment of impoverished racial minorities is also upheld as a valid exercise of legitimate legislative purposes. ${ }^{52}$ In fact, referring to the function of the "permissible legislative purpose" criterion (i.e. that prohibiting "discrimination") in the context of the reasonable classification test, a Note in the Harvard Law Journal observed that the criterion was simply a caveat: ${ }^{53}$

... against the assertion that "this classification is valid because it is rationally related to the purpose of promoting inequality." ... [t]he courts will ordinarily require the showing of a purpose which works in some way to promote the general welfare. ... By contrast, a similar judgment made about the worth of individuals would require clear justification.

Discrimination, especially in the present context of equality before the law, is not a situation that can be assessed in a vacuum. Some Canadian cases have shown signs of moving towards this recognition

48 To demand instead that the government "undertake a program of affirmative action to end the worst racial discrimination" (Lyon, at 57) is to beg the question. It is precisely the function of the Bill of Rights to protect individuals when the government does not act to end racial discrimination but perpetuates it. This is a continuing task of vigilance and sensitivity. Furthermore, Professor Lyon's approach assumes that an attempt at a wholesale revision of the Indian Act is likely to be more efficacious in fact than intelligent judicial activism when required. Indeed, are the two mutually exclusive?

17 In fact, several American cases have upheld governmental "wardship" legislation as not discriminatory. See Lone Wolf (1903) 187 U.S. 553; U.S. v. McGowan (1937) 302 U.S. 535 and U.S. v. Washington (1956) 233 F. (2d) 811.

48 Supra, n. 4 at 226.

4t Supra, n. 35 at 355.

so Curr v. Q. (1972) 26 D.L.R. (3d) 603 at 611 . For example of a form of discrimination not encompassed in s. 1 but which was held capable of denying equality before the law, see $R$. v. Burnshine [1974] 4 W.W.R. 49.

31 See McLaughlin v. Florida (1964) 379 U.S. 184 at 192, and Loving v. Virginia (1967) 388 U.S. 1.

52 See Katzenbach v. Morgan (1966) 384 U.S. 641. See also Kaplan, Equal Justice in an Unequal World: Special Treatment for Blacks, (1966) 61 Nw. U. L. Rev. 363. This approach has been upheld in the decision of the Permanent Court of International Justice in Advisory Opinion on Minority Schools in Albania [1935] P.C.I.J., Ser. A, No. 15; Ser. C, No. 14-II; digest, Ser. E, No. 4, at 191.

so Note, Developments in the Law: Equal Protection, (1969) 82 Harv. L. Rev. 1065 at 1081. 
but, as in the Indian Act cases, the movement is often unsettled and inconclusive. However, Chief Justice Jackett of the Federal Court of Appeal put the issue clearly in the case of Re Prata: ${ }^{54}$

... it is of the essence of sound legislation that laws be so tailored as to be applicable to such classes of persons and in such circumstances as are best calculated to achieve the social, economic or other national objectives that have been adopted by Parliament. Application of a substantive rule of law to one class of persons and not to another cannot, as it seems to me, of itself, be objectionable discrimination form the point of view of s. 1(b) of the Canadian Bill of Rights. This is not to say that there might not be a law that is essentially discriminatory by reference to some other prejudice, in the same sense as a law can be discriminatory "by reason of race, national origin, colour, religion or sex". Such a law, to the extent that it was thus discriminatory, would not, I should have thought, be a law based on acceptable (that is, it would not be acceptable, having regard to the Canadian Bill of Rights, unless enacted "notwithstanding the Canadian Bill of Rights") legislative objectives adopted by Parliament and would to that extent, run foul of s. 1(b) of the Canadian Bill of Rights. (emphasis added)

In the more recent case of $R$. v. Burnshine, there was clearly a "differential treatment" of individuals under s. 150 of the Prisons and Reformatories Act as youths in certain parts of the country were subject to more substantial periods of incarceration than were adults or youths elsewhere. Despite this, Martland J. spoke for the entire court when he said that the respondent still had an obligation "at least, to satisfy this Court that, in enacting s. 150, Parliament was not seeking to achieve a valid federal objective". ${ }^{55} \mathrm{Mr}$. Justice Laskin dissented (Spence and Dickson JJ. concurring) but on the issue of the reasonableness of the penalty imposed.

\section{B. Reasonable Classification}

In this dissent, Mr. Justice Laskin was, in fact, utilizing the second stage of the reasonable classification test. That is, even though the seemingly "discriminatory" classification in Burnshine could be justifiable in light of a "legitimate legislative purpose", the scope of the classification and the treatment imposed on the group within the classification had also to be "reasonable" when compared with the legislative objective (the "mischief"). Concerning the scope of the classification, the issue is whether it includes either too few peoples possessing the relevant trait ("under-inclusive") or too many ("overinclusive"). For example, if the legislative intention is to preserve "Indian" identity, does the group excluded by the legislation possess the traits that destroy the identity? Over-inclusive classifications are clearly most offensive (they include persons entirely unrelated to the legislative objectives) but both over or under-inclusive classifications, where they are "unreasonable", deny equality before the law and must be remedied. In this regard, it should be noted that those "extraordinarily suspect" classifications such as race and sex will rarely ever pass this second stage of judicial analysis. This is so because the legislative purpose would, in most cases, be better defined by reference to the specific trait or characteristic that is relevant to the mischief than to the broad groupings that are usually encompassed by the suspect classifications.

Concerning the nature of the treatment imposed on the classified group, this is not an aspect of "reasonable classification" that is often

ss [1974] 4 W.W.R. 49 at 60. 
considered. It is, however, a logical part thereof when one appreciates that it is "equality before the law" that is being evaluated. As Laskin J. commented in Burnshine, the effect of the challenged 8.150 of the Prisons and Reformatories Act allowed such excessive additional imprisonment beyond the limits stipulated in the Criminal Code that it was "on its face ... alien to the very purpose which is said to animate it". Instead there should be:56

... an umbrella of equality of permitted length of punishment and within that limit a scope for relaxing its stringency to accommodate a rehabilitative and correctional purpose.

In passing, it is interesting to look again at the Gonzales case in light of the present discussion. It will be recalled that Tysoe $J$. defined "equality before the law" in terms of:57

. . . a right in every person to whom a law relates or extends, no matter what may be a person's race, national origin, colour, religion or sex, to stand on an equal footing with every other person to whom that particular law relates or extends. . . .

Ritchie J. was indeed correct when he commented that this would legitimize the "most glaring discrimination"-because the definition proposed in the case was only concerned with the implementation of classifications once drawn. The American case, McLaughlin v. Florida, rejected this partial approach in terms similar to those of Ritchie $J$. in Drybones. The case showed how the two-stage test must be applied:58

Judicial inquiry under the Equal Protection Clause, therefore, does not end with a showing of equal application among the members of the class defined by the legislation. The Court must reach and determine the question whether the classifications drawn in a statute are reasonable in light of its purpose-in this case, whether there is an arbitrary or insidious discrimination between those classes covered . . . and those excluded.

\section{ANALYSIS APPLIED-THE INDIAN ACT CASES}

\section{A. General Problem}

Before turning to an application of this test to the specific cases, a few very important general problems shoud be pointed out. Indeed, perhaps the most crucial question in this whole debate is whether it really is possible for two separate and often culturally incompatible societies to co-exist within one geographic national unit. This is the issue facing the courts and the legislature. ${ }^{59}$

An interesting case to illustrate this general problem of compatibility is Ex Parte Crow Dog. ${ }^{60}$ Until this case arose in 1883 , native Indians in the United States were free to manage their own internal affairs.

s6 Id. at 68. One could, however, disagree with the comparison Laskin J. makes with the Criminal Code (it is, as in Canard, discrimination per se that is at issue) but he preferred in Burnshine "to support a construction that would clearly be compatible with the Canadian Bill of Rights than to embark upon an inquiry that could entail an examination of the reality of the policy. . .." (At 67.)

37 Gonzales, supra, n. 17 at 297.

so McLaughlin v. Florida (1963) 379 U.S. 184 at 184.

so It manifests itself in a number of ways, the most dramatic being the current debate over native land claims. Commenting on the government's early reaction to these claims, L. C. Green observed that federal policy (in its 1969 "White Paper") was: ". . . based on the central assumption that any legislation which sets a particular segment of the population aside from the main stream of the citizenry is ipso facto conducive to a denial of equality and therefore discriminatory and to be deplored. Such an assumption indicates a complete lack of understanding of the concept of equality, particularly insofar as this concept has been embodied in laws for the protection of minorities." Green, Canada's Indians: Federal Policy, International and Constitututional Law, (1970) 4 Ottawa L. Rev. 101 at 101. This assumption has been expressly rejected by the federal government since Professor Green's article. See the statement of policy by the Hon. Jean Crétien, Minister of Indian Affairs and Northern Development, August 8, 1973.

60 (1883) 109 U.S. 656. 
However when Crow Dog, according to a particular tribal custom, was not executed for the murder of Spotted Tail, an outraged public demanded "justice" in accord with their developed Western sensibilities.61 In 1885 therefore the Major Crimes Act was enacted and extended to Indians restricting their cultural autonomy. Similarly the Bill of Rights has been extended to Indian society even though that society is based on a tribal community and not on the liberal individualism of the dominant culture. Commenting on the situation in the United States, the Director of the Indian Law Center has written:62

The effect of the 1968 Civil Rights Act on Indian Tribes will be serious and, in some areas, threaten the survival of Tribes. I agree . . . that civil rights are here to stay, but the implementation of the Civil Rights Act can either strengthen or destroy tribal governments. The threat is posed by eager civil rights enthusiasts who seek to impose upon tribal governments their own particular brand of civil rights without realizing the consequences of their action on tribalism. In many tribal situations, tribal interests or community interests transcend so-called individual civil rights to the extent necessary for tribal survival.

These sentiments have been often echoed in the Canadian context as the Bill of Rights, ". . . intended as a shield to protect minority groups such as Indians, was almost used as a club to victimize them." 63 At a time when the detrimental effects of an excessively individualistic society are becoming increasingly threating (particularly familiar are those crises in the energy, environmental and natural resource fieldsnot to mention myriad political and social tensions), is it wise to ignore without examination the communal values of the indigenous Canadian peoples? The potential loss is enormous as one can readily appreciate by contemplating the likely fate of that most renowned of communal cultures, the Inuit.

A second important motivation for considering the Indian Act's legislative purpose is the historical special status that Indians do have in relation to Canadian white society. This is central to an understanding of the importance of the legislative provisions as the co-existence of this special group with the "white man" is in fact based upon a quasicontractual arrangement embodied in treaties and given legislative status through the BNA Act and the Indian Act. It has been argued that the special protection thus afforded the Indians is consideration for the sacrifices made by them. For this reason, unilateral amendment of the terms of the contract through the Bill of Rights is steadfastly opposed by the status Indians represented through the Act. On the other hand the Act does represent status Indians only; often (as in the Lavell case) at the expense of underprivileged and unprotected Metis and "half-breeds". In dealing with s. 91(24), all "Indians" must be considered.

To do justice to both Acts, therefore, requires a careful consideration by the judiciary of the real underlying purposes of the Indian Act when applying the Bill of Rights. Considering the inability of the Court to substitute a better provision when a discriminatory one is declared inoperative, the Court is in a very difficult position. This cannot be denied. For example, in Lavell, Mr. Justice Laskin cited a number of status native organizations in opposition to the case for Mrs. Lavell. The opposition was often based NOT on the merits of the claim but on a fear

61 John White, American Indian Civil Rights: A Paradox, in Materials on Native Rights (ed. Cumming) (1975) at 158 .

62 Bennett, Book Review, (1970) Washington U.L.Q. 218 at 219

os Supra, n. 33 at 209. See also Sanders, The Bill of Rights and Indian Status (1972) 7 U.B.C. L. Rev. 81. 
that in striking down the discrimination, nothing would be left. Indeed, years prior to the case, one such status native organization, the Union of Ontario Indians, had actually proposed that: 64

Indian women who marry non-status Indians or non-Indians should be able to retain their Indian status for a period of time or for as long as they wish ... [whereas] the present Act regards them as intruders in their own home community.

Judicial hesitation in light of such fears is not justified. Firstly, even the most extreme decision of the Court could only be to declare a particular provision "inoperative" for that specific case. It cannot void the provision entirely and it would not, in any event, destroy the Act's operation. Furthermore, although it is beyond the judicial function for the Court to substitute its opinion for the legislature (a point equally well recognized in the United States), the Bill of Rights does instruct the Court to "construe" a potentially discriminatory provision so as to apply it without discrimination (where possible). This is an open invitation to imaginative decision-making such as would reflect the necessities of the Indian Act. In any event, despite the opposition of many native Canadians to judicial intervention, the role of the Court cannot be denied-the Act is legislation and cases will continue to arise. Indeed, native organizations have themselves not hesitated to seek out judicial protection in some areas-most notably, land claims ${ }^{65}$-while criticizing the Court's interference in others.

The role for the Court advocated here clearly presents problems for the Canadian judiciary as it has traditionally operated. As Tussman pointed out, the search for legislative purpose "involves the Court in the thornier aspects of judicial review". Especially in cases where discrimination is hidden and legislative purpose unclear, the only alternative is that: ${ }^{66}$

... the Court must uncritically and often unrealistically accept a legislative avowal at its face value. [Alternatively] it must challenge legislative integrity and push beyond the express statement into unconfined realms of inference ... then ... make a judgment as to ... the legitimacy of the end. Only after the purpose of the law has thus been discovered and subjected to this scrutiny can the Court proceed with the classification problem.

Canadian courts have not been willing, as a rule, to take this step and the Indian Act cases are no exception. As W. S. Tarnopolsky has written: 67

... the conclusion of the majority in the Lavell case illustrates that a reference to 1960 definition merely camouflages the fact that the judges of the Supreme Court are giving their own interpretations to the words used, instead of following the three principal rules of statutory construction to see what Parliament intended.

The three rules are to examine the "plain meaning" of the provision, its context and the "mischief" at which the statute was aimed. This latter approach in particular could yield fruitful results: 68

In the interpretation of statutes, it is the duty of the Court to ascertain the real intention of the legislature by carefully regarding the whole scope of the statute to be construed.

\footnotetext{
of Union of Ontario Indians, Brief on Changes to Indian Act, in Materials on Native Rights (ed. Cumming) (1975) at 90.

es See Calder [1973] S.C.R. 313.

6s Su;ra, n. 35 at 367.

67 Supra, n. 28 at 169.

su Morrison v. M.N.R. [1928] Ex. C.R. 75 (per Audette J.).
} 
This search for legislative intent should not involve the Court in a subjective assessment of motive. Instead, it should be objective in nature focussing on "the terms of the statute, its operation and its context, both legal and practical in which it was passed".69 Beyond that (in order to assess the reasonableness of the classification) the Court has recourse to legislative history and to the effect, over time and in changing circumstances, of the classifications used in fulfilling the purposes of the Act. This will involve the Court in much sociological and historical analysis but, as is evident from the land claims cases, it is quite equal to that task.

If we are to resolve the conflict between the Indian Act and the Bill of Rights so as to employ the latter to guarantee to the Indians those human rights which are not seriously incompatible with the continuance of their cultural autonomy (such a choice has not yet arisen) then a serious analysis such as is recommended here is required. Indeed, Paul Weiler has, on the centenary of the Supreme Court's creation, advocated a generally increased social role for it. It is, as he says, "high time to get the scholarly task underway."70

\section{B. Specific Application-the Cases}

Historically s. 91(24) and the Indian Act were a product of the agreements reached as a result of the interaction between the Indian people and the European colonizers. In exchange for relinquishing their claims to "aboriginal title" to all the lands of British North America, the Indians were given protected reserves and some broader special rights (such as hunting and fishing). The Indian Act was to solidify these agreements both by deterring encroachment by the white man onto the reserves while also assisting in the orderly development of the Indians. Ultimately such development was to lead to the integration and assimilation of the Indian into white society ${ }^{71}$ through voluntary enfranchisement.

The evolution of the Indian Act did not go according to plan. So paternalistic is that statute that the native population was channelled into a state of dependency and degradation. Limited "development" took place and the articles permitting "enfranchisement" (s. 108-s. 113) remained almost forgotten. Some individuals have been enfranchised but no band in its entirety has utilized the enfranchisement provision. Now, almost in spite of the Act, a developing Indian consciousness is asserting itself and its demands are not those of the Indian Act. In particular, the policy of assimilation has been rejected but the special treatment the legislation accords to "status" Indians-through the reserves, through the taxation exemptions, through the controls on white man's access to and expliotation of the reserve and through the status definitions-are seen as essential by that portion of the native population. If it smacks of apartheid that is only because it has been insufficiently modernized and developed through joint agreement. But

69 Supra, n. 53 at 1091.

70 Weiler, Of Judges and Scholars: Reflections in a Centennial Year (1975) 53 Can. Bar Rev. 563 at 575. His article strongly advocates "the positive values of judicial law reform" (at 569). The present author recognizes the reluctance of the judiciary to substitute its opinions for that of the legislature. In discovering and applying the "legitimate legislative intention" it could not, however, even be accused of this.

71 Writing in 1946, Allan G. Harper asserted: "The Act's true essence is guardianship; i.e. the special protection of Indians in their persons and property, coupled with a positive governmental responsibility for their welfare and advancement." Harper, Canada's Indian Administration: The Indian Act, (1946) 5 American Indigence 297. 
for many, the special status is crucial as the Indian's "Red Paper", Citizens Plus, points out: ${ }^{72}$

$\ldots$ in addition to the normal rights and duties of citizenship, Indians possess certain additional rights as charter members of the Canadian Community. . . [ [t]he recognition of Indian status is essential for justice.

Today, these aspirations are finally being recognized by the federal government. ${ }^{73}$

Much of this discussion may not be explicitly relevant to judicial decision-making but some points are basic: the Act is to be protective of a way of life that is different from that of the dominant culture and it is also to foster the Indian's "development"-a concept clearly antithetical to racial paternalism. The reserves and the special rights are central to the protection and development. This is the "mischief" of the Act.

Looking at the specific cases, it is essential first, to identify the nature of the groups that are being treated differently (that is, the factor distinguishing a special group) and, second, to isolate that element with regard to which the group is specially treated. Does the purpose that is revealed by this special treatment reflect a legitimate legislative intention? If so, is the classification of the group "reasonable"?

The three cases at hand are of two types. First, Drybones and Canard deal with incidents of "Indianness". That is, there is no question in the cases that the people involved were Indians and the Court should only have been asking whether the disabilities being imposed upon them were justifiable in light of this "Indianness". Does it justify special treatment when they are drunk or when one of them dies? On the other hand, the Lavell case poses a more difficult and serious question-that of status. But the issue is the same again-given the legislative goal of protecting "Indianness", is the special treatment accorded Mrs. Lavell and Mrs. Bedard justifiable?

In Drybones, the groups being compared were individual Indians and individual non-Indians and the element with regard to which the Indians were being penalized was drunkenness. This was not a question of being treated more harshly-the issue was whether being an individual Indian justified any restrictions being imposed alone upon you with regard to drunkenness? Is there some legitimate difference in the individual (and that is what s. 95(b) deals with-the individual Indian who is intoxicated) that justifies particular treatment? Clearly the answer is "no". There is only a racial distinction. A drunk is a drunk and drunkenness is not unique to Indians.

This is not to deny that a sociological problem may exist. But the section is not aimed at that and even if it were, the classification is so under-inclusive (non-Indian drunks being excluded) and so over-inclusive (Indians not alcoholics but who are, in one instance, intoxicated) as to be unreasonable. But the section is clearly not aimed at that sociological problem. It is aimed at the individual drunk and, by treating Indians specially without justification, it is discriminatory and it denies equality before the law. In contrast, should the government seriously want to attack the problem in a non-discriminatory way, it could, for example,

72 Indian Chiefs of Alberta, Citizen's Plus. The document is often called the Red Paper as it was submitted to the Prime Minister in rebuttal of a governmental "White Paper" proposing abolition of special status for the Indians.

73 See statement of policy by the Minister of Indian Affairs, August 8, 1973. 
set up rehabilitation centres for Indians. This would reflect a legitimate governmental concern for Indians as a group. Its purpose would be benign not punitive and it would not penalize individuals for a problem not unique to them.

The provision in issue is, therefore, clearly contrary to the Bill of Rights. Furthermore, holding the section to be inoperative is of no damage to the ostensibly protective motivation behind it. ${ }^{74}$ Should the provision be removed in toto (which should eventually happen if it is discriminatory, rather than just being held inoperative in the particular case), the Indians would be subject to the generally applicable federal, or, as in this case, provincial laws. The same end is accomplished by these laws without discrimination while at the same time disposing of the self-deception that the special article actually represents some form of an attack on the general problem.

The Canard situation is, in essence, almost parallel to the Drybones case. Mr. Justice Dickson's decision in the Manitoba Court of Appeal is, in particular, most instructive. Although his final ratio seems very sweeping, it is prefaced by the very important observation that: ${ }^{75}$

... so long as there are Indian reserves there must be, I should think, limitation of the right of Indians to alienate, inter vivos or by will, the lands of the reservation or any estate or interest therein. Some restriction is essential to the preservation of the treaties and the integrity of the reserves. But control of testamentary capacity is not a necessary incident to the control of land. In the present case the land or an interest therein is not, so far as I am aware, a factor. The estate of Mr. Canard consists of a money claim. Even if an interest in land did form part of an estate, the administrator would take such interest subject to whatever restriction or alienation had earlier been imposed.

Insofar, therefore, as the purpose of the control of wills is restricted to control of reserve lands (itself a legitimate purpose as we have seen), it would seem that s. 42 and s. 43 are unreasonably excessive and should be so "applied and construed" in the particular case. This would then restrict the whole discretionary power of the Minister to control the administration of Indian estates to where it could be shown to be in fulfillment of the valid legislative purpose with regard to the preservation of Indian lands.

This was not the analytical approach taken in the Supreme Court of Canada. The decision was of a very technical nature and there is, as a result, a paucity of information and analysis on the purpose and operation of the challenged sections. The factum of the intervenant National Indian Brotherhood, ${ }^{76}$ however, points out that the only wills controlled by the original statutory provisions were those of reserve land holders while other Indian wills were then of doubtful validity. ${ }^{77}$ This was changed by amendments in 1894 making all wills valid subject to the overriding control of the Minister. The amendment therefore originally served an enabling function which clearly is no longer necessary-as the fact of Mrs. Canard's appointment as administratrix under the general Manitoba law reveals. The native intervenants, however, ever wary of judicial intervention, support the provisions today

\footnotetext{
74 It is perhaps apposite to note that without examining legislative motive we are able to discern true legislative intent by looking at the "mischief" of the legislation and the impact of the challenged provision.

2s Canard [1975] 5 W.W.R. 678 at 690.

${ }^{76}$ Factum of National Indian Brotherhood, Intervenant in A.G. (Can.) v. Canard at S.C.C. level. Made available to author by Department of Indian Affairs, Regional Office, Toronto.

77 Johnson v. Jones and Tobicoke (1895) 31 Canadian Law Joumal 101 (Ontario Chancery Division).
} 
with the paternalistic rationale of high illiteracy among native peoples and frequent isolation of them from legal advice.

The policies therefore are basically protection of reserve lands and paternalism. This latter policy is no ground at all for depriving underprivileged minorities of their rights and is totally unsupportive of the restrictive policy found in the Act and its Regulations. Dickson J.A. has argued that the broad control exercised under the sections (resulting in a denial of the right to administer the estate) is also not justified by this first policy. Indeed, it is questionable to me whether control of wills is at all necessary to control reserve lands. It should definitely not reduce Indian testamentary capacity in general. In this light, Laskin J. may have been correct not to render the section inoperative but to declare instead that it be applied consistently with s. 1(b) of the Bill of Rights. This would severely restrict ministerial powers yet without being seen to amend the Act. With so little information available on the subject it is not possible to see if in fact such powers could ever be justified in light of more specific alternatives. But if they could not, the section should not just be "construed" without discrimination but should be held inoperative. ${ }^{78}$

While Martland J. of the majority did consider the legislative purposes of the sections, he failed to consider the reasonableness of their exercise. Restating his position in Burnshine, he said that: ${ }^{79}$

... federal legislation which applied to a particular group or class of people . . . did not offend against that guarantee [under the Bill of Rights] if it was enacted in order to achieve a valid federal objective.

Although this general statement is agreeable enough as a first step, the conclusions, without analysis, are not: ${ }^{80}$

In my opinion there are legitimate reasons of policy for the enactment of such provisions in relation to the estate assets of deceased Indians ordinarily resident on reserves.

With respect, it is suggested that such a partial application of the reasonable classification test cannot lead to a fair result for either the Indian Act or the Bill of Rights.

The sort of test applied to these two cases bears marked similarities to statements made by Beetz J. in Canard and by Professor Lyon. Beetz J. would have the Bill of Rights strike down legislation that is "so remote and indirect an incident as not to be indispensable to the effective exercise of the federal power under s. 91(24)."81 Unfortunately, Mr. Justice Beetz's approach leads to the sort of wholesale exemption found in Lavell rather than examining all provisions as to their legitimacy and reasonableness. Professor Lyon, on the other hand, appreciates the logic of such examination: ${ }^{82}$

That is, the fact that a law applies to Indians and to Indians only may not by itself make it a law in relation to Indians. The law might have to be shown to relate somehow to the special character of Indians in order to qualify as a law in relation to Indians.

\footnotetext{
7N Unlike all the judges in the Supreme Court-who found the provisions to be within the jurisdiction of the federal government under 8 . 91(24)-the approach recommended here would effectively remove these sections from federal competence.

79 Supra, n. 5 at $560-61$.

Bo Id. at 561 .

si Id. at 577 .

82 Supra, n. 40 at 59.
} 
On the other hand, as we have seen, Professor Lyons argues that on balance both the Bill of Rights and the Indian Act would benefit more from judicial non-interference than from judicious intervention.

The Lavell situation, unlike Drybones or Canard, dealt with provisions that were central to the operation of the Indian Act-those determining status. It was the centrality of this determination that dictated Mr. Justice Ritchie's "hands off" judgment, but, with respect, such a result was not inevitable. Indeed, Ritchie J.'s reasoning utilizes only the first half of the reasonable classification argument and, by ignoring the second step, he inevitably comes to illogical and incomplete conclusions.

With regard to the purpose of $\mathrm{s} .12$, it is clear that discrimination cannot be established simply by examining the legislative intention behind the disputed section. Recourse to the "reasonableness" test is also necessary. Indians as Indians are covered by the BNA Act for specific purposes and it is therefore necessary to define those having the status of "Indian" in order to fulfill the purposes of the Act. The Indian Act necessarily defines criteria for status to ensure the protection, firstly, of the identity of the group as Indians, and secondly, from encroachment onto the reserves of exploitative white men. These are valid legislative purposes which can be determined from an examination of the Act itself and from the mischief at which it is aimed. But, as Mr. Justice Laskin has pointed out, "discriminatory treatment . . . does not inhere" in the exercise of such a function.

Having discovered valid legislative purposes for the disputed section, the next stage is to assess whether the classifications employed are reasonable in light of the particular purposes. Is it reasonable to exclude Indian women marrying white men from status as Indians in order to protect the larger collective entity? As the sexual criterion for classification is one that is "extraordinarily suspect", the onus on the defenders of the Act is a very heavy one and they must discharge it by showing that, with reference to the necessary cultural and sociological elements of "Indianness", sexual differentiation is necessary. Mr. Justice Laskin criticized this approach saying that it "compounds racial inequality even beyond the point that the Drybones case found unacceptable."Bs Yet if Indians are a minority that is to be protected (as they themselves hope), how else except with reference to criteria reflecting "Indianness"? This can become the basic problem of incompatible cultures but, in this case at least, we are not yet in the dilemma of Ex Parte Crow Dog.

Looking at the first purpose, the preservation of the identity of the bands, one must consider that the legislature has chosen to rely upon a "kinship system" of status-determination whereby membership is determined not by blood ties or way of life but by the structural relationship to the nuclear family. One such structural relationship is "non-Indian male married to Indian female". The legislative kinship system under the Indian Act rejects this relationship excluding both individuals from the definition of "Indian" even though a full-blooded white wife of a male Indian becomes a registered status Indian. ${ }^{84}$ From a common sense viewpoint, this classification is both under and over inclusive. Indeed, it seems to be totally non-racial! But is it reasonable in the circumstances?

sus Supra, n. 4 at 224.

s4 For details on the operation of the kinship status determination, see Sanders (1972) 7 U.B.C. L. Rev. 81 . 
Substantial sociological analysis would be necessary to answer this question. Insofar as the kinship system is just a convenient legislative construction, it is unsupportable as it is based on sexual discrimination. Insofar as it is the best arrangement available to protect the identity of the band, the differential benefit over alternative arrangements must be weighed against the fact of sexual discrimination in light of the dual goals of the reasonable achievement of the valid legislative policies and the implementation of the Bill of Rights. This is not to trench upon the legislative function-it is simply to test it in accordance with the direction of the Bill of Rights. On the one hand, to the extent that the section is, for example, an integral part of an important patrilineal Indian culture, it may be defended. In fact, patrilineage is generally consistent with the Indian culture (although its present importance is uncertain) BUT, significantly, the Iroquois Six Nations tribe (from which Mrs. Bedard comes) and some British Columbia bands are traditionally matrilineal! This tends therefore to undermine this particular justification for the overall classification-at least from an historical viewpoint. However, the Court must also look at the section in its current cultural context. To what extent has the provision become internalized into Indian life as it presently exists?"85 Does this require its retention? This is, of course, not an easy sociological question and if there is an alternative that does not involve sexual classifications while protecting the "Indian" identity, then the provision is clearly unreasonable and discriminatory. When one considers the arbitrary distinctions s. 12 makes between brother and sister and between the children of mixed marriages and when one realizes the arbitrary secondclass status that has been created in the Metis as a result of this and similar provisions, surely the judicial identification of individual instances of legislative discrimination could only stimulate governmental action to relieve the most glaring discrimination.

The major purpose of the section is clearly the prevention of the encroachment of white men onto the reserve. This purpose is a wellknown historical one and is obviously the central rationale today. For the first forty years of the Act women did not lose their status-just their reserve rights. This was changed in 1869 to deny the woman her status as an Indian as well as access to the reserve. In 1956, Parliament amended s. 12 again to clarify the question of whether she could return to the reserve after the death or divorce of her white husband. The amendment, rather gratuitously, insisted that her status would return only on marriage to an Indian. This degree of treatment at least is surely indefensible given either legislative purpose. Interestingly, that amendment is highly relevant to Mrs. Bedard's appeal as her purpose in joining with Mrs. Lavell was to be allowed to return to the reserve after a judicial separation from her white husband. Could it be construed to have a less damaging effect or should it be entirely inoperative?

To assure the protection of these reserves, one could conceive of equally effective alternative classifications that are available. For example, the Act could simply deny the non-Indian husband and his wife any further property rights than they had on their marriage. More strict than this but less extreme than the present Act, the section could deny them access to the reserve but without loss of status for the woman

4s See Sanders, Indian Women: A Brief History of their Roles and Rights, (1975) 21:4 McGill L.J. 656 at $668-672$. In evaluating this issue, it is crucial that a broad range of argument be available to the Court. 
and her children (as before). Considering that the right to access to the reserve is the most important of the status qualifications, it is especially important that any exclusion from it be reasonable and nondiscriminatory. But it does seem clear that the denial of status and residence to Mrs. Bedard on the spearation from her husband is excessive and unjustified by the legislation. The section should be construed and applied to prohibit this sort of discrimination-much as Laskin J. recommended be done in Burnshine. As well, Mrs. Lavell's exclusion from the reserve would also be unnecessarily harsh and, without a very good explanation of the reasonableness of the classification, her denial of status would also be unreasonable and discriminatory.

\section{CONCLUSION}

The arguments just presented for each case are not exhaustive but it is this pattern of argument that the courts should, I suggest, be encouraging. ${ }^{86}$ The decisions that would result would be offensive to neither the Bill of Rights nor the British North America Act. Neither would they be a "trenching" upon the Parliamentary function even though they would certainly stimulate that body to remedial action in an area of blatant discrimination. By attacking the problem in an incremental fashion, chaos would be avoided and orderly, rational development encouraged. That the supremacy of Parliament has been theoretically restricted with the passage of the Bill of Rights is almost academic in light of the profound judicial timidity in dealing with matters of policy. Perhaps more explicit legislation will be required to force the courts to act. But the powers to do justice to both the Bill of Rights and the Indian Act exist already.

no For a more detailed exposition of the sorts of issues that should be considered, see Sanders, id. 